\title{
Identifikasi Molekul Adhesi Pili Pseudomonas aeruginosa pada Human Umbilical Vein Endothelial Cells (HUVECS) Culture
}

\author{
Dwi Yuni Nur Hidayati*
}

\author{
Program Studi Biomedik, Fakultas Kedokteran, Universitas Brawijaya, Malang
}

\begin{abstract}
Abstrak
Pseudomonas aeruginosa merupakan salah satu penyebab Gram negatif bakteriemia yang bisa berlanjut menjadi sepsis. Bakteri ini banyak menginfeksi penderita di rumah sakit dengan membentuk koloni pada pembuluh darah melalui proses adhesi (pelekatan). Pili dan bagian Outer Membrane Protein (OMP) adalah faktor yang mempengaruhi pelekatan bakteri $P$. aeruginosa. Tujuan dari penelitian ini adalah untuk mengetahui berat molekul protein hemaglutinin yang terdapat pada pili dan membuktikan peran protein hemaglutinin pada pili dalam pelekatan bakteri $P$. aeruginosa. Metode yang digunakan dalam penelitian ini adalah isolasi protein pili $P$. aeruginosa secara bertingkat, dilanjutkan dengan uji hemaglutinasi (metode mikrotiter) dan uji adhesi menggunakan protein pili hasil elektroelusi yang disalutkan pada kultur sel endotel (HUVECS) (konsentrasi 1, 1/2, 1/4, 1/8, 1/16 dan 0 [kontrol]). Hasil penelitian menunjukkan adanya reaksi hemaglutinasi pada potongan pili ketiga dengan titer tertinggi (1/128). Protein hemaglutinin dengan berat molekul 38,19 kDa memberikan titer tertinggi (1/16). Hasil uji adhesi protein hemaglutinin yang disalutkan pada sel endotel menunjukkan bahwa semakin tinggi pengenceran maka adhesi bakteri menunjukkan peningkatan secara signifikan dengan konstanta regresi $(r)=0,98$ dan $p$ value $=0,00$. Berdasarkan penelitian dapat disimpulkan bahwa protein hemaglutinin pili merupakan protein adhesin. Protein adhesin dengan berat molekul 38,19 kDa berperan pada perlekatan bakteri $P$. aeruginosa 9064 dengan kultur sel endotel (HUVECs).
\end{abstract}

Kata kunci: adhesi, hemaglutinasi, pili, Pseudomonas aeruginosa

\section{PENDAHULUAN}

Peningkatan kejadian dan problema penyakit infeksi yang biasanya dikaitkan dengan keadaan negara berkembang dan kebersihan yang kurang, ternyata tidak seluruhnya benar. Di Amerika Serikat, kematian akibat sepsis tiap tahunnya mencapai 70.000 orang. Sekitar $50-60 \%$ sepsis disebabkan oleh bakteriemia Gram negatif. Penyebab Gram negatif bakteriemia yang paling sering terjadi adalah famili Enterobacteriaceae dan Pseudomonaceae, terdiri dari Escherichia coli (35\%), Klebsiella, Enterobacter, Proteus (38\%) dan Pseudomonas aeruginosa (12 \%) [1].

Pseudomonas aeruginosa ( $P$. aeruginosa) adalah bakteri Gram negatif berbentuk batang, bergerak dengan flagel, dan bersifat aerob. Bakteri ini banyak menginfeksi penderita di rumah sakit dengan predisposisi tertentu. Banyak faktor-faktor penentu patogenitas dari bakteri ini diantaranya yang berhubungan dengan struktur sel seperti pili (fimbriae) dan bahan yang dikeluarkan seperti exotoxin A dan protease [2].

\footnotetext{
* Alamat korespondensi penulis:

Dwi Yuni Nur Hidayati

e-mail : hidayati@yahoo.co.id

Alamat : Laboratorium Biomedik, Fakultas Kedokteran Universitas Brawijaya, Jl. Veteran, Malang, 65154
}

Kontak langsung antara agen infeksi dengan sel inang diawali dengan proses adhesi (perlekatan) [3]. Bakteri P. aeruginosa dapat melakukan adhesi dan membentuk koloni pada bermacam-macam tipe sel yaitu epitel sel buccal, paru, ginjal dan sel endothel [3]. Adhesin bakteri Gram negatif diperankan oleh suatu protein yang mampu mengaglutinasi eritrosit mamalia protein ini disebut dengan protein hemaglutinin, salah satu contoh adalah protein adhesin Klebsiella pneumoniae yang diperankan oleh protein hemaglutinin $29 \mathrm{kDa}$ [4].

Penemuan bahwa adhesi merupakan tahap awal proses infeksi pada sebagian besar bakteri, menunjukkan bahwa protein adhesin tersebut memiliki potensi sebagai komponen vaksin yang baik. Salah satu contoh adalah Fim $H$ vaccine yang sedang dikembangkan untuk mencegah infeksi saluran kemih yang disebabkan E. coli [5]. Kemampuan bakteri untuk melekat dan menembus sel endotel merupakan akibat dari interaksi adhesin-reseptor antara bakteri dan permukaan sel endotel [6]. Molekul reseptor tergantung pada jenis bakteri. Molekul reseptor terdapat di enterosit epitel vesica urinaria atau endotel. Bakteri Pseudomonas aeruginosa melekat selektif terhadap sel-sel endotel manusia [7]. 
Penelitian mengenai pengaruh protein adhesin yang terdapat pada pili sebagai faktor virulensi pada proses adhesi dengan sel endotel Human Umbilical Vein Endothelial Cells Culture (HUVECs) sebagai tempat pelekatan bakteri $P$. aeruginosa belum ada yang melaporkan. Berdasarkan uraian di atas diharapkan dapat dilakukan identifikasi protein adhesin dengan menentukan besarnya berat molekul protein hemaglutinin bakteri $P$. aeruginosa.

\section{METODE PENELITIAN}

\section{Sampel Penelitian}

Isolat bakteri Pseudomonas aeruginosa yang digunakan pada penelitian ini diperoleh dari bahan pemeriksaan klinik yang diperoleh di Laboratorium Klinik Mikrobiologi Rumah Sakit Saiful Anwar (RSSA) Malang yang mempunyai titer aglutinasi tinggi. Jenis Penelitian yang digunakan dalam penelitian ini adalah eksperimental laboratorik, dengan desain Posttest Only Kontrol Group Design. Setiap unit percobaan terdiri satu well kultur endotel yang didalamnya terdapat cover slip. Masing-masing perlakuan diinkubasi dengan $P$. aeruginosa. Kelompok kontrol adalah bakteri Pseudomonas aeruginosa yang dilakukan uji adhesi tanpa penambahan konsentrasi protein pili. Sedangkan kelompok perlakuan adalah bakteri $P$. aeruginosa yang dilakukan uji adhesi dengan penambahan konsentrasi protein pili yang berbeda.

\section{Metode Kultur Pseudomonas aeruginosa}

Bakteri yang digunakan berasal dari koleksi Laboratorium Mikrobiologi RSSA. Bakteri ditumbuhkan pada media TCG. Sebelum bakteri ditumbuhkan dalam media TCG, bakteri terlebih dahulu ditumbuhkan dalam media TCBS dan diinkubasi selama 24 jam pada suhu $24{ }^{\circ} \mathrm{C}$. Biakan yang telah tumbuh diambil dan ditanam pada media TCBS (inkubasi 24 jam suhu $24^{\circ} \mathrm{C}$ ). Biakan yang tumbuh diambil dengan cara dikerok, sebelumnya dituangkan PBS steril $\mathrm{pH}$ 7,4 secukupnya. Suspensi bakteri tersebut dimasukkan ke dalam botol yang berisi 1000 ml larutan Brain Heart Infusion Broth (BHI). Suspensi tersebut dikocok kuat selama 30 menit pada penangas air $37{ }^{\circ} \mathrm{C}$. Suspensi bakteri diambil sebanyak $10 \mathrm{ml}$ dan dimasukkan ke dalam media TCG dan diinkubasi selama 48 jam pada suhu $37{ }^{\circ} \mathrm{C}$.

\section{Metode Isolasi Pili Pseudomonas aeruginosa}

Metode isolasi pili bakteri ini merujuk dari Ehara [8]. Bakteri dipanen dari botol biakan bakteri dan selanjutnya hasil koleksi ditambahkan Tri Chloroacetic Acid (TCA) sampai konsentrasi 3\% dan dihomogenasi. Suspensi kemudian disimpan pada suhu kamar selama satu jam dan dilanjutan dengan sentrifugasi kecepatan $6.000 \mathrm{rpm}$ selama 30 menit pada suhu $4{ }^{\circ} \mathrm{C}$. Pelet diambil dan diresuspensi dengan cairan $\mathrm{PBS} \mathrm{pH} 7,4$ dengan perbandingan antara pelet dan cairan 1:10. Bakteri kemudian dicukur menggunakan mixer yang telah dirancang khusus untuk pencukuran pili di Laboratorium Mikrobiologi Politeknik Universitas Brawijaya Malang. Bakteri dicukur dengan kecepataaan penuh selama satu menit, diulang sampai lima kali dengan masa istirahat satu menit. Hasil yang diperoleh dari pencukuran pili bakteri kemudian disentrifugasi selama 30 menit, kecepatan 12.000 rpm, pada suhu $4{ }^{\circ} \mathrm{C}$. Pili yang terletak pada bagian supernatan diambil. Endapan (pelet) diresuspensikan dengan larutan dan cara yang sama, kemudian dikumpulkan dengan mencukur ulang beberapa kali sampai dihasilkan supernatan yang menunjukkan tes aglutinasi negatif.

\section{Metode Isolasi Protein Hemaglutinin Pili} $P$. aeruginosa

Pili yang telah dikoleksi selanjutnya dilakukan SDS-PAGE. Sel dipotong lurus pada berat molekul yang diinginkan dan potongan pita tersebut dikumpulkan dan dimasukkan pada tabung membran. Selanjutnya pita dianalisis menggunakan larutan penyangga elektroforesis (running buffer). Kemudian dilanjutkan dengan analisis elektroelusion menggunakan sistem elektroforesis horizontal aparatus dengan aliran $125 \mathrm{mV}$ selama 25 menit. Hasil elektroforesis dielusi dengan larutan pengangga PBS pH 7,4 selama 48 jam masing-masing dua liter dan diganti tiga kali. Cairan hasil elusi, yang berasal dari potongan pita SDS-PAGE tersebut dilakukan uji hemaglutinasi.

Sodium Dodecyl Sulfate Polyacrylamid Gel Electrophoresis (SDS-PAGE)

Monitoring berat molekul dikerjakan menggunakan SDS-PAGE metode Laemmli [9]. Sampel protein dipanaskan $100{ }^{\circ} \mathrm{C}$ selama lima menit dalam larutan penyangga yang mengandung 5 $\mathrm{mM}$ Tris $\mathrm{HCl} \mathrm{pH} \mathrm{6,8,} \mathrm{5 \%} \mathrm{2-mercapto} \mathrm{ethanol,}$ $2,5 \%$ sodium dodecyl sulfate, $10 \%$ glyserol dengan warna pelacak bromophenol blue. Dipergunakan $12,5 \%$ mini slab gel dengan tracking gel 4\%. Voltase yang digunakan $125 \mathrm{mV}$. Sebagai bahan pewarna adalah coomassie brilliant blue dan molekul standar sigma low range marker.

\section{Metode Uji Hemaglutinasi}

Uji hemaglutinasi dikerjakan menurut Hanne and Finkelstein [10]. Sel darah merah dicuci sebanyak tiga kali menggunakan PBS dengan cara 
sentrifugasi, kecepatan 3000 rpm masing-masing selama 10 menit. Pengenceran sampel dibuat kon-sentrasi $1 / 2$ dan volume $50 \mu$ l pada tiap sumur mikroplat V. Tiap sumur ditambahkan suspensi darah merah mencit konsentrasi 0,5\% dengan volume sama. Kemudian digoyang dengan menggunakan rotator plate selama satu menit. Selanjutnya diletakkan pada suhu kamar selama satu jam. Besarnya titer ditentukan dengan pengamatan adanya aglutinasi darah merah pada pengenceran yang terendah. Sampel yang diuji adalah bakteri Pseudomonas aeruginosa, protein pili. Jenis darah merah yang digunakan adalah darah manusia dan tikus. Aglutinasi dibaca apabila terlihat hasil aglutinasi (aglutinat) pada dasar sumuran plat titer micro dengan kontrol negatif. Titer hemaglutinasi dihitung berdasarkan angka kebalikan pengenceran tertinggi yang masih menunjukkan aglutinasi. Setiap uji dilakukan replikasi sebanyak tiga kali.

\section{Isolasi dan Pembuatan Kultur Sel Endotel}

Semua bahan yang akan digunakan dihangatkan hingga $37{ }^{\circ} \mathrm{C}$. Umbilikus dibersihkan dari debris sel dengan tissue. Masing-masing ujung umbilikus dipotong transversal sehingga terlihat dua arteri dan vena (dinding yang lebih tebal, lebih besar dan lentur). Selanjutnya kanul dimasukkan pada satu ujung vena (klem) kemudian diikat dengan erat. Vena dibersihkan dengan PBS A melalui kanul yang terpasang dengan menggunakan spuit $20 \mathrm{~cm}$. Ujung umbilikus yang tidak memiliki kanul diikat kuat. Selanjutnya kolagenase dimasukkan ke dalam vena seperti cara memasukkan kanul dan dibiarkan spuit terpasang pada kanul. Selanjutnya umbilikus didekap dengan tangan (agar suhu mencapai $37^{\circ} \mathrm{C}$ ) selama 8 menit.

Kolagenase (mengandung sel endotel) dikeluarkan dengan cara diambil dengan spuit yang masih terpasang dan dipindahkan pada tabung sentrifugasi steril. Cara seperti pemberian kolagenase diulang tetapi dengan menggunakan $8 \mathrm{ml}$ PBS A. Larutan tersebut kemudian diambil kembali seperti pada cara sebelumnya. Larutan yang mangandung sel endotel disentrifugasi dengan kecepatan $1300 \mathrm{rpm}$ selama 8 menit. Sentrifugasi diulang sebanyak dua kali dengan ditambahkan $2 \mathrm{ml}$ media. Supernatan yang terbentuk dipisahkan dan pelet diresuspensi dengan $4 \mathrm{ml}$ media kultur. Supernatan yang diperoleh diinkubasi dalam inkubator ( $5 \% \mathrm{O}$ dan $95 \% \mathrm{CO}_{2}$ ).

Pada hari berikutnya media diambil dan dicuci dengan menggunakan serum free media, kemudian diisi lagi dengan $4 \mathrm{ml}$ media kultur. Setiap dua hari sekali setengah dari media diambil dan diganti dengan yang baru. Sel endotel akan berbentuk sebagai monolayer pada hari ke-3 dan selanjutnya di subkultur.

\section{Metode Pengecatan Struktur}

Pengecatan struktur endotel dilakukan dengan menggunakan cat warna Gram (kristal violet, lugol, aseton-alkohol $96 \%$ dan safranin) dan Giemsa (Wright dan buffer sample). Kaca benda yang berisi sel endotel dalam well dicuci bersih dan dikeringanginkan dalam inkubator dengan suhu $37{ }^{\circ} \mathrm{C}$. Selanjutnya ditetesi dengan larutan Wright secara merata diatas cover slip selama 3 menit. Larutan selanjutnya diambil dengan jarum suntik dan dibilas dengan buffer sample selama 10 menit. Buffer diangkat dengan jarum suntik kemudian cover slip dikeringanginkan dalam inkubator $37{ }^{\circ} \mathrm{C}$. Dilakukan pengamatan struktur endotel pada mikroskop inverted dan mikroskop DIC (Different Inferent Contrast) dengan perbesaran 200 kali, 400 kali dan 1000 kali.

\section{Metode Uji Adhesi}

Uji adhesi menggunakan metode modifikasi Nagayama et al. [11]. Biakan cair bakteri $P$. aeruginosa disentrifugasi $(6.000 \mathrm{rpm}, 10$ menit, suhu $4{ }^{\circ} \mathrm{C}$ ). Suspensi bakteri diambil sebanyak $100 \mu \mathrm{l}$ (kandungan bakteri sekitar $10^{8}$ $\mathrm{ml}^{-1}$ ) dan dimasukkan well yang didalamnya terdapat kaca benda berisi sel endotel. Well dimasukkan dalam shaking inkubator dengan pergerakan rotor 60 kali per menit, selama 30 menit, dengan suhu $37{ }^{\circ} \mathrm{C}$, kemudian kaca benda dalam well dicuci sebanyak tiga kali dengan PBS steril (calcium free). Kaca benda dengan kristal violet dibilas dengan air selama satu menit, kemudian dicuci dengan lugol selama satu menit, dibilas dengan air dan dicuci dengan asetonalkohol $96 \%$ selama satu menit, dibilas dengan air dan dicuci dengan safranin. Preparat dibilas lagi dengan air, kemudian dikeringanginkan. Dilakukan pengamatan model adhesi bakteri Pseudomonas aeruginosa pada sel endotel, dan model struktur sel endotel. Model adhesi diamati menggunakan mikroskop dengan pembesaran 200 kali, 400 kali, dan 1000 kali, serta dilakukan perhitungan indeks adhesi yaitu jumlah rata-rata bakteri yang menempel tiap 100 sel endotel.

\section{Metode Uji Hambatan Adhesi}

Metode uji hambatan adhesi merujuk pada Sumarno [12]. Bakteri $P$. aeruginosa diencerkan hingga Optical Density (OD) 1. Sampel protein pili hasil elektroelusi diencerkan dengan seri pengenceran masing-masing $1 / 2$ kali dengan menggunakan PBS steril pH 7,4 sebanyak $500 \mathrm{ml}$ dan 
selanjutnya dimasukkan ke dalam sumuran yang berisi cover slip kultur endotel (inkubasi pada water bath dengan suhu $37{ }^{\circ} \mathrm{C}$, shaker dengan pergerak-an rotor 60 kali tiap menit selama 30 menit). Bakteri $P$. aeruginosa OD 1 dimasukkan sebanyak $200 \mu \mathrm{l}$ pada masing-masing cover slip yang berisi endotel. Dilakukan inkubasi dengan shaker incubator dengan kecepatan rotor 60 kali tiap menit, pada suhu $37{ }^{\circ} \mathrm{C}$ selama 30 menit. Cover slip yang berisi endotel diangkat dengan pinset, difiksasi, dan dilakukan pengecatan Giemsa Gram. Masing-masing pewarnaan dilakukan selama satu menit. Cover slip dikeringanginkan dan dilakukan penghitungan uji hambatan adhesi.

\section{Teknik Analisis Data}

Data dianalisis menggunakan analisis korelasi antara perubahan indeks adhesi dan perubahan konsentrasi protein pili hemaglutinin.

\section{HASIL DAN PEMBAHASAN}

\section{Uji Hemaglutinasi \& SDS-PAGE}

Uji hemaglutinasi dilakukan untuk mencari protein hemaglutinin $P$. aeruginosa dengan titer tertinggi yang berasal dari sepuluh isolat dan protein hemaglutinin yang berasal dari pili (fimbriae) setelah biakan bakteri dipotong dengan alat omnimixer modifikasi [8]. Pada uji saring mencari protein hemaglutinin dari 10 isolat bakteri Pseudomonas aeruginosa diperoleh isolat Pseudomonas aeruginosa 9064 dengan titer $1 / 64$ dan fraksi pili (fimbriae) diperoleh titer $1 / 128$ pada uji hemaglutinasi menggunakan eritrosit mencit (Tabel 1). Selain itu, dari hasil uji hemaglutinasi protein pili $P$. aeruginosa menunjukkan titer hemaglutinasi dari potongan pili ketiga (P3) paling tinggi dengan titer 1/128. Berdasarkan kedua data tersebut diketahui bahwa bakteri $P$. aeruginosa 9064 memiliki protein hemagglutinin (HA) yang berasal dari pili (fimbriae).

Hasil SDS-Page Isolasi Bertingkat Protein Pili P. aeruginosa 9064

Berdasarkan hasil analisis SDS PAGE potongan pili yang memiliki sifat aglutinasi eritrosit mencit, diperoleh tiga gambaran berat molekul pita protein yang paling menonjol dari potongan protein pili ketiga, yaitu 57,17 kDa, 38,19 kDa dan 32,1 kDa. Gambaran ketiga protein yang menonjol tersebut dipotong untuk dikoleksi, selanjutnya dilakukan pemurnian untuk elektoelusi sehingga didapatkan protein larutan. Protein untuk elektroelusi seperti terlihat pada Gambar 1.

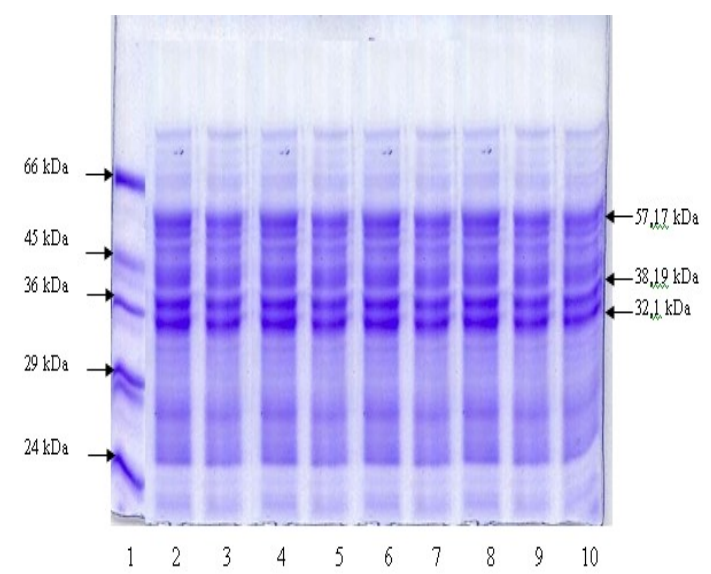

Gambar 1. Hasil elektroforesis SDS-PAGE protein Pili potongan ke-3 untuk Elektroelusi

Keterangan : 1 : protein perunut 2-10 : potongan Pili 3

Tabel 1. Titer Hemaglutinasi dari berbagai isolat bakteri $P$. Aeruginosa

\begin{tabular}{|c|c|c|c|c|c|c|c|c|c|c|c|c|}
\hline \multirow{3}{*}{ Materi } & \multicolumn{12}{|c|}{ Sumur } \\
\hline & 1 & 2 & 3 & 4 & 5 & 6 & 7 & 8 & 9 & 10 & 11 & 12 \\
\hline & $(1 / 2)$ & $(1 / 4)$ & $(1 / 8)$ & $(1 / 16)$ & $(1 / 32)$ & $(1 / 64)$ & $(1 / 128)$ & & & & & $\mathrm{K}$ \\
\hline Ps0865 & + & + & + & - & - & - & - & - & - & - & - & - \\
\hline Ps9475 & + & + & + & + & - & - & - & - & - & - & - & - \\
\hline Ps0670 & + & + & + & - & - & - & - & - & - & - & - & - \\
\hline Ps1019 & + & + & + & + & + & - & - & - & - & - & - & - \\
\hline Ps0881 & + & + & + & + & - & - & - & - & - & - & - & - \\
\hline Ps0614 & + & + & + & + & - & - & - & - & - & - & - & - \\
\hline Ps9476 & + & + & + & + & - & - & - & - & - & - & - & - \\
\hline Ps9064* & + & + & + & + & + & + & - & - & - & - & - & - \\
\hline Ps0871 & + & + & + & + & - & - & - & - & - & - & - & - \\
\hline Ps3418 & + & + & + & - & - & - & - & - & - & - & - & - \\
\hline
\end{tabular}




\section{Uji Hemaglutinasi terhadap Berbagai Jenis Eritrosit}

Uji hemaglutinasi ini bertujuan untuk mengamati hemaglutinasi terhadap eritrosit manusia golongan darah $A, B, A B, O$ dan darah mencit. Hasilnya dapat diihat pada Tabel 1. Berdasarkan data yang diperoleh dapat diketahui bahwa titer hemaglutinasi protein pili 38,19 kDa memberikan hasil positif dengan eritrosit manusia golongan darah $\mathrm{O}(1 / 16)$ dan eritrosit mencit $(1 / 32)$ sedangkan dengan eritrosit manusia golongan $A, B$ dan $A B$ memberikan hasil negatif.

\section{Uji Adhesi Protein Hemaglutinin}

Uji adhesi bertujuan untuk membuktikan bahwa protein hemaglutinin pili 38,19 kDa merupakan protein adhesin, sebagai faktor virulensi yang memiliki kemampuan untuk melekatkan bakteri $P$. aeruginosa pada sel hospes, dalam hal ini adalah sel endotel (HUVECs). Berdasarkan pengamatan terhadap uji adhesi protein hemaglutinin pada enam perlakuan (Gambar 2) dan berdasarkan hasil perhitungan indeks adhesi $P$. aeruginosa pada sel endotel (HUVECs) yang disalut protein hemaglutinin 38,19 kDa tersebut memberikan gambaran bahwa, semakin tinggi konsentrasi protein hemaglutinin yang diberikan maka akan menurunkan indeks adhesi.

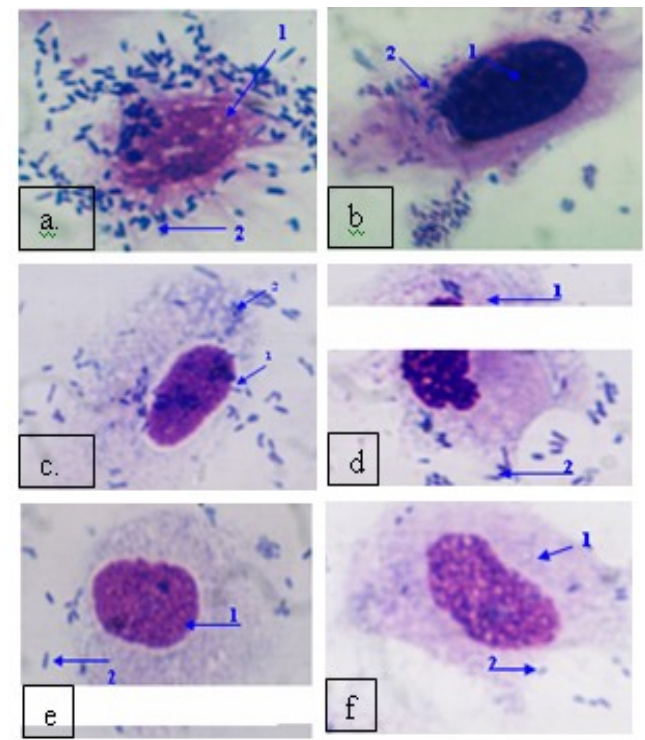

Gambar 2. Uji adhesi protein hemaglutinin (Foto mikroskup Nikon pembesaran 1000 kali

\section{Keterangan:}

a. kontrol ( $P$. aeruginosa pada sel endotel)

b. perlakuan protein hemaglutinin $38,19 \mathrm{kDa}$ konsentrasi $1 / 16$

c. perlakuan protein hemaglutinin $38,19 \mathrm{kDa}$ konsentrasi $1 / 8$

d. perlakuan protein hemaglutinin $38,19 \mathrm{kDa}$ konsentrasi $1 / 4$

e. perlakuan protein hemaglutinin $38,19 \mathrm{kDa}$ konsentrasi $1 / 2$

f. perlakuan protein hemaglutinin 38,19 kDa

konsentrasi 1

1. Sel endotel HUVECs

2. Sel bakteri $P$. Aeruginosa.

Analisis lebih lanjut dengan menggunakan analisis regresi dan varian $(\alpha=0.05)$ menunjukkan bahwa terdapat perbedaan yang signifikan pada masing-masing perlakuan yang diberikan. Kecen-derungan peningkatan konsentrasi protein hemaglutinin terhadap indeks adhesi, dapat dilihat pada Gambar 3. Berdasarkan hasil analisis varian satu jalur (ANOVA) diketahui bahwa dosis pengenceran protein hemaglutinin berpengaruh signifikan terhadap indeks adhesi $P$. aeruginosa pada sel endotel HUVECs dengan signifkansi F hitung $(p)=0,00$ dan tingkat kepercayaan $95 \%$. Hasil analisis perbandingan masing-masing perlakuan melalui (Tukey's test), menunjukkan bahwa masing-masing dosis pengenceran memberikan hasil yang berbeda secara signifikan dengan tingkat kepercayaan 95\%, jika dibandingkan semua perlakuan. Berdasarkan hal tersebut, diketahui bahwa pemberian protein hemaglutinin pili 38,19 kDa dapat menurunkan indeks adhesi.

$P$. aeruginosa mempunyai dua tipe $p$ itein adhesi yaitu protein adhesi yang terdapat sada pili dan yang terdapat pada permukaan se (non pillus adhesins). Pili $P$. aeruginosa yang digu kan pada penelitian ini merupakan pili tipe 4 lang hampir sama dengan pili yang dimiliki $b$ kteri Nesseria gonorrhoeae dan Vibrio choler [2]. Bakteri Gram negatif berinteraksi d Igan lingkungan luar menggunakan faktor vir ensi termasuk toksin ekstraseluler, pili, :urli, autotransporter, dan crystalin S-layers [13]. Hal ini membuktikan bahwa $P$. aeruginosa mempunyai protein adhesin dari pili potongan ketiga dengan berat molekul 38,19 kDa.

Adhesi $P$. aeruginosa pada sel endotel HUVECs ditentukan oleh faktor virulensi berupa pili. Penelitian lain menyebutkan bahwa bahwa Pseudomonas aeruginosa juga mengaktivasi sel $\mathrm{M}$ manusia untuk menginduksi migrasi neutrophil transendothelial melalui sel $M$ yang berasal dari IL-1 $\alpha$ dan IL-1 $\beta$ [14]. Penelitian lebih lanjut diperlukan untuk mengetahui kemungkinan penggunaan mekanisme adhesi oleh HUVECs untuk menginfeksi endotel. Diduga adhesi $P$. aeruginosa terhadap endotel ditentukan oleh sekresi protein dengan general secretory pathway (GSP) yang merupakan dua bagian 
proses yang membutuhkan Sec translocase didalam inner membrane dan suatu substrat pemisah sekresi spesifik aparatus selama sekresi menyeberangi outer membran. Salah satu faktor virulensi $P$. aeruginosa untuk berinteraksi dan komunikasi dengan inang yang termasuk dalam GSP adalah pili $[2,13]$.

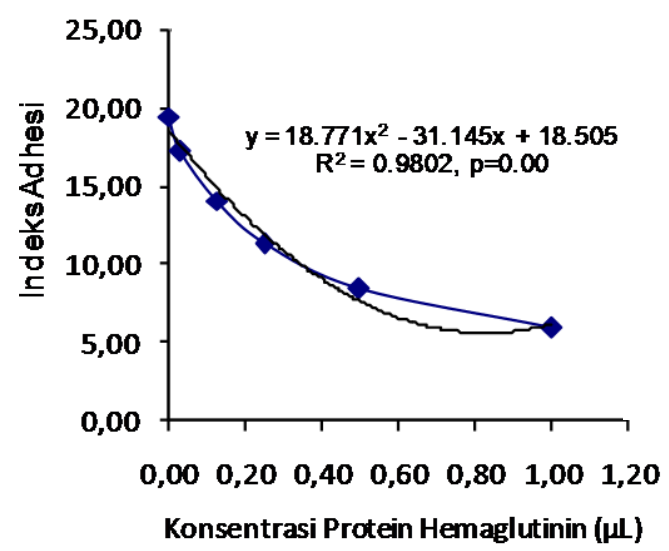

Gambar 3. Kecenderungan peningkatan konsentrasi protein hemaglutinin terhadap indeks adhesi

Pili tipe IV $P$. aeruginosa merupakan pseudopilin yang didisain oleh protein PulG, PulH, Pull, dan PulJ. Semua protein termasuk prepilin peptidase cleavage dan bagian methilasi dan hampir semuanya terletak pada periplasma. Struktur pili ini merupakan pilus yang menyeberangi periplasma (tabung sekresi), berfungsi untuk memfasilitasi transport PulA menuju Outer Membran (OM). Dalam hal ini pili seperti protein, merupakan sistem sekresi pullulanase yang melibatkan tipe 4 prepilin seperti signal peptidase yang disusun oleh PilO yang sangat penting untuk sekresi protein PulA.

Comer et al., menjelaskan $P$. aeruginosa strain 1244 mempunyai pilin glycan yang berikatan secara kovalen terhadap residu serin [15]. Hasil sequencing N-terminal dari fraksi pilin dihasilkan dari perlakuan endopeptidase dan diidentifikasi dengan reaksi monoklonal antibodi spesifik glycan yang terindikasi bahwa glycan berada diantara residu 75 dan terminus pilin karboksil. Bagian karboksil-proksimal pada pilin disulfida loop, yang di ukur pada pilin glycan, merupakan epitop sel B linear utama, ini sebagai epitop peptida.

Pili dari $P$. aeruginosa pada dasarnya merupakan protein fiber yang memanjang dari satu atau kedua sel pole. Proses ini merupakan faktor penting untuk virulensi yang mem- perantarai proses adhesi pada jaringan sel inang. Pili mampu meluas dan beretraksi, sebuah bagian yang mempengaruhi kolonisasi dan memfasilitasi proses twitching, sebuah bentuk motilitas yang sangat penting dalam dessiminasi patogen. Pili $P$. aeruginosa merupakan bentuk tetap dari sebuah subunit monomerik, pili yang mempunyai berat molekuler antara $15 \mathrm{kDa}$ hingga $17 \mathrm{kDa}$ dan mempunyai karakteristik yang berhubungan dengan pili tipe IV. Salah satu karakteristik ini adalah adanya methylated amino-terminal phenylalanine. Hal ini menunjukkan bahwa, pada modifikasi post translasional pili $P$. aeruginosa 1244 merupakan glikosilasi dan modifikasi ini membutuhkan adanya fungsi dari gen PilO.

Hasil penelitian menunjukkan bahwa berat molekul potongan pili ketiga adalah 38,19 kDa. Seperti dijelaskan oleh peneliti terdahulu bahwa pili $P$. aeruginosa merupakan pili sub unit monomerik tetapi berat molekulnya adalah 15 kDa sampai $17 \mathrm{kDa}$, setelah ditentukan ternyata gen penyandinya adalah PilO. Diduga berat molekul 38,19 kDa merupakan berat molekul sub unit monomerik dengan jenis gen penyandi yang berbeda, sehingga perlu dilakukan penelitian lebih lanjut untuk menentukan bentuk protein dengan berat molekul tersebut. Selain itu, diperlukan penelitian lebih lanjut tentang jenis protein dan analisis gen penyandi protein $P$. aeruginosa.

Castric et al., juga menjelaskan bahwa pili $P$. aeruginosa merupakan pili somatik, filamen protein yang meluas seperti benang dari satu atau kedua sel poles, yang merupakan faktor virulensi utama, memicu adherensi pada sel inang dan proses invasi pada sel inang [16]. Berat molekul protein pili ini berkisar antara 16 kDa. Bentuk mature dari protein ini dihasilkan oleh pergerakan dari suatu six-residue leader sequense sebuah proses yang diatur oleh metilasi pada nascent amino-terminal phenylalanine. Deter-minasi proses ini tergantung jenis gen penyadi PilO, yaitu sebuah gen yang terletak pada bagian operon yang juga mengandung pili struktural gen PilA. Berat molekul kisaran $16 \mathrm{kDa}$ diketahui sebagai berat molekul penentu patogen opportunistik pada bakteri Gram negatif $P$. aeruginosa. Berdasarkan kajian literatur tersebut perlu ditentukan apakah berat molekul protein dari hasil penelitian potongan pili ketiga 38,19 kDa isolat Ps 9064 juga merupakan patogen oppurtunistik terhadap sel inang khususnya sel endotel HUVEC.

Mekanisme invasi $P$. aeruginosa whole cell pada sel endotel HUVEC normal berdasarkan 
hasil penelitian menunjukkan bahwa struktur morfologi sel endotel kultur yang dicat dengan pewarnaan Wright Giemsa dan pengamatan dengan mikroskop merk Nikon menunjukkan bahwa tampak bentuk sel pipih, dengan struktur sitoplasma dan inti sel yang masih jelas, dan secara morfologis belum menunjukkan adanya perubahan morfologis secara nyata.

Gambaran adhesi bakteri $P$. aeruginosa menunjukkan pola aggregat dan ada pula yang berpola diffuse atau menyebar pada permukaan sel endotel. Kultur sel endotel yang telah diperlakukan dengan adhesi $P$. aeruginosa dan disalut dengan protein pili hemaglutinin pada potongan pili ketiga dengan berat molekul 38,19 $\mathrm{kDa}$ dengan berbagai dosis pengenceran menunjukkan bahwa semakin besar dosis protein hemaglutinin yang disalut pada sel endotel kultur menunjukkan adanya tingkat penghambatan adhesi yang semakin besar. Semakin besar pengenceran yang diberikan, memberikan gambaran adhesi yang lebih besar dibandingkan dosis pemberian protein hemaglutinin tanpa pengenceran. Kecenderungan peningkatan konsentrasi protein hemaglutinin terhadap indeks adhesi, dapat dilihat pada Gambar 3. Berdasarkan Gambar 3, diketahui bahwa semakin besar tingkat pengenceran maka terjadi peningkatan adhesi bakteri secara signifikan dengan nilai regresi $(r)=0,98$ dan $p$ value $=0,00$. $\mathrm{Hal}$ ini diduga terdapat hubungan yang signifikan antara pili dengan berat molekul 38,19 kDa dengan adhesi $P$. aeruginosa pada sel endotel kultur normal. Berdasarkan titer tertinggi pada pengenceran protein pili potongan protein hemaglutinin pada dosis $1 / 16$ adhesi $P$. aeruginosa menunjukkan adhesi yang meningkat bila dibandingkan dengan dosis 1 dan dosis pengenceran $1 / 2,1 / 4$ dan $1 / 8$. Hasil ini menunjukkan adanya pengaruh pemberian protein hemaglutinin terhadap indeks adhesi bahwa semakin besar konsentrasi protein adhesin pili (fimbriae) yang disalutkan pada sel endotel kultur makin kecil indeks adhesi bakteri $P$. aeruginosa. Hasil penghitungan indeks adhesi $P$. aeruginosa pada sel endotel juga menunjukkan semakin besar dosis pengenceran protein pili (fimbriae) yang disalut pada sel endotel maka indeks adhesi bakteri juga semakin besar.

\section{KESIMPULAN DAN SARAN \\ Kesimpulan}

Berdasarkan analisis hasil penelitian dapat disimpulkan bahwa hasil pemotongan pili pada bakteri $P$. aeruginosa 9064 didapatkan protein hemaglutinin dengan berat molekul 38,19 kDa. Semakin besar dosis protein hemaglutinin yang disalutkan pada sel endotel (HUVECs), maka semakin kecil nilai adhesi bakteri $P$. aeruginosa. Saran

Perlu dilakukan analisis molekuler lebih lanjut terhadap protein hemaglutinin pili $P$. aeruginosa dengan berat molekul 38,19 kDa. Hal ini bertujuan untuk membuktikan kemungkinan pili potongan ketiga dengan berat 38,19 kDa merupakan salah protein hemaglutinin dan merupakan satu faktor virulensi pada sel endotel normal.

\section{DAFTAR PUSTAKA}

1. Virella, G. 1997. Gram-negative Rods III: Oppor-tunistic and Zoonotic Bacteri; Microbiology and infectious disease $3^{\text {rd }}$ edition. Williams and Willins awaverly Company. Philadelpia.

2. Salyers, A.A., D. Whitt. 1994. Bacterial Pathogenesis. ASM Press. Washington DC.

3. Comolli, J.C., L.L. Waite, K.E. Mostov, J.N. Engel. 1999. Pili Bending to Asialo-GM 1 on Epithelial Cells Can Mediate Cytotoxicity or Bacterial Internalisation by Pseudomonas aeruginosa. Infection and Immunity. 67. 7:3207-3214.

4. Martino, P.D., Y. Bertin, J.P. Giradeau, V. Livrelli, B. Joly. 1995. Molecular Characterization and Adhesive Properties of CF29K an Adhesin of Klebsiella pneumoniae Strain Involved in Nosocomial Imfection. Infection and Immunity 67:700-707.

5. Wizemann, T.M., J.E. Adamoum, S. Langermann. 1999. Adhesins as Targets for Vaccine Develop-ment. Centers for Disease Kontrol and Prevention. USA.

6. Tompkins D.C., V.B. Hatcher, D. Patel, G.A. Orr, C.L. Higgins, F.D. Loury. 1985. A Human Endothelial Cell Membrane Protein that Binds StaphyloCoccus aureus In Vitro. J.Clin Invest. 65:1248-1254.

7. Plotkowski, M.C., A.M. Saliba, S.H. Pereira, M.P. Cervante, O. Bajolet-Laudinat. 1994. Pseudomonas aeruginosa selective adherence to and entry into human endothelial cells. Infection and Immunity. Dec. 62:5456-5463.

8. Ehara, M., M. Ishibashi, Y. Ichinose, M. Iwanaga, S. Shimotori, T. Naito. 1987. Purification and Partial Characterization of Pili of Vibrio cholerae 01. Vaccine 5:283-288.

9. Laemli, U.K. 1970. Cleavage of Structural Protein During Assembly of The Head of Bacteriophage T.4. nature 227:680-685. 
10. Hanne, L.F., R.A. Finkelstein. 1982. Characterization and distribution of the hemagglutinins produced by Vibrio cholerae. Infection and Immunity. April. 36. 1:209-214.

11. Nagayama, K., T. Oguchi, M. Arita, T. Honda. 1995. Purification and Characterization of $A$ Cell Associated Haemagglutinin of Vibrio parahaemolyticus. Infection and Immunity. 63. 5:1987-1992.

12. Sumarno. 2000. Karakterisasi Molekuler Protein Adhesi Vibrio Cholerae 01 M094V dan Protein reseptornya pada Sel Epitel Usus Halus Tikus Putih (Wistar). Tesis. Program Pascasarjana Universitas Airlangga. Surabaya.

13. Stathopoulos, C., D.R. Hendrixson, D.G. Thanassi, S.J. Hultgreen. 2000. Secretion of Virulence determinants by the general secretory pathway in Gram-negative pathogens: an evolving story. Microbes and infection. 2:1061-1072.

14. Lin-Tong, J., G. Rafael, R.T.M. Boudreau, A.C. Issekutz. 2002. Pseudomonas aeruginosa Activates Human Mast Cells to Induce Neutrophil Trans-endothelial Migration Via Mast Cell-Derived IL-1 $\alpha$ and IL-1 ${ }^{1}$. Journal Immunology. 169:4522-4530

15. Comer, J.E., M.A. Marshal, V.J. Blanch, C.D. Deal. 2002. Identifification of the Pseudomonas aeruginosa $1244 \quad$ Pili glycosylation Sit. Infection and Immunity. 70. 6:2837-2845.

16. Castric, P., F.J. Cassels, R.W. Carlson. 2001. Sructural Charcterization of the Pseudomonas aeruginosa 1244 Pili Glycan. Journal of Biological Chemistry. 270. 28:26479 $-26485$. 